\title{
Research on Motivation of Transferring Secondary Vocational School Teachers from Enterprises
}

\author{
Meihuan $\mathrm{Xu}$, Jianrong Zhang \\ Tongji University, Shanghai, China
}

\begin{abstract}
Under the paradigm of qualitative research, we explored the process and reasons for the nine technologists to abandon the highpaying positions of the company to enter the middle-level teachers. Based on the interview data, we used the rooted theory to establish the motivation for the transfer of the transferred teachers. The study found that "reasons of separation" and "individual needs" are the two main categories that constitute "transfer motivation"; "transfer motivation" under the influence of "preconditions", "catalytic factors" and "obstructive factors" and "teacher occupation" The advantage "matches; if the match is successful, the idea of "deciding to become a secondary school teacher" is generated and put into action. Through cross-case analysis, it outlined the career transition profile of the transferred teachers, including the "family fulfillment" type, which is driven by "free time", the "start another stove" type, which is driven by "burnout", and is dominated by "personal ideals" motivated "long-term planned" type. Based on the results of this research, we proposed to contract and recruit enterprise technical talents in secondary vocational schools, and propose the cooperation channel between schools and enterprises as the recruitment channel, and establish the support policy and salary incentive system strategy for enterprise personnel.
\end{abstract}

Sci Insigt Edu Front 2019; 4(1):369-386.

Doi: 10.15354/sief.19.ar221

Keywords: Secondary Vocational Teachers; Career change teacher; Corporate Background; Transfer Motivation

About the Author: Jianrong Zhang, Professor, Vocational and Technical Education College, Tongji University, Shanghai 201804, China,Email: zhangjr@tongji.edu.cn. 


\section{Background}

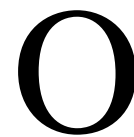

N January 24, 2019, the "Professional Education Reform Implementation Plan" issued by the State Council of the People's Republic of China stated that "from 2019 onwards, vocational colleges and applied undergraduate colleges and related professional teachers have in principle more than 3 years of corporate work experience and Individuals with higher vocational education or above are openly recruited, and special high-skilled personnel (including those with senior engineers or above) can appropriately decrease their academic qualifications. From "enterprise personnel to school-appointed teachers" to "full-time teachers with more than three years of work experience" "It demonstrates China's urgent need for a high-quality faculty and a firm determination to build a "double-educational" faculty. At the same time, the enterprise experience of secondary vocational teachers is self-evident for the promotion of classroom quality and teacher development. Australia DEST A report in (2003) pointed out that in addition to addressing the shortage of teachers, the benefits of the career change teacher to the school include professional knowledge and real life experiences, and can also motivate students to have a passion for the profession. Highly skilled personnel with a background in business have significant advantages in professional and social experience. Encourage a range of skills, experiences, abilities, and interests into the classroom to improve the quality and effectiveness of education (Richardson, 2001) and to help students develop professional culture (Long Chenghai, 2009). The challenge of teachers and the establishment of a "double-type" teacher team have always existed. How can secondary vocational schools attract and cultivate the talented craftsmen with their corporate background to inject new vitality into the secondary vocational classrooms? It must be traced back to the high-skilled talents transferred to become secondary vocational teachers. Motivation issues have arisen, and novice teachers who have transferred jobs have been the focus of attention (Anthony G, 2008).

Since the 1990s, research on transfer teachers has become a research hotspot in the field of foreign teacher education (Zhang, 2013). In particular, extensive research has been conducted on the motivations of their teaching work. The results show that they choose to teach because of internal and altruistic reasons, rather than external rewards. The greatest motivation comes from working with children, supporting the growth and development of students and the desire to contribute to society (Serow,

Correspondence to: Meihuan Xu, Master's Candidate, Vocational and Technical College, Tongji University, Shanghai 201804, China, Email: 13296455619@163.com.

Funding: Shanghai Philosophy and Social Science Planning Project "Study on the Connotation and Development Model of Professional Ability of Secondary Vocational School Teachers" (Project No.: A1708, Moderator: Zhang Jianrong)

Conflict of Interests: None. 
1994; Goh, 2001; Richardson, 2006). Serow (1994) proposed "inner rewards" in the study of 40 transfer teachers, for example to help or influence the reasons most often mentioned by students. Lerner's (2002) study found that the motivation for a career change in a transfer teacher is "want to make a difference and pursue meaningful work"; the study by Salyer (2003) supports this claim: the mainstay of the professional transferee is identified. The motivation factor is "hoping to help students and contribute to society". Although a large number of studies have shown that intrinsic and altruistic motivations are a high priority for most transferred teachers, Hobsen (2004) and others found "long holidays (68\%)" "Work security (69\%)" External rewards such as "teaching occupational status (63\%)" are important considerations for choosing teaching as a career, although the scores for these factors are not as high as the internal factors. According to Manuel's (2006) report, 34\% and 19\% of participants believe that "lifestyle considerations" and "working conditions" are important; Richardsn (2008) found that for many people, family-friendly working conditions and safety and the flexibility of employment is important, while economic factors and social status are less important. At the same time, the researchers conducted a classification study on transfer teachers based on different motivations for transfer, and proposed different classification methods (see Table 1 for details).

Due to different economic forms and national conditions, the roads and models for the development of secondary vocational education in China are also far from those of other countries. Whether it is for the discussion of the internal and external motivations, or the classification of teachers according to the characteristics of the motivation for transfer, there is a lack of research on localization in China. At the same time, due to the problem of language differences, "career change teacher" often refers to the change of posts from primary school teachers to kindergarten teachers, but the "teacher" career has not been changed. Therefore, under the current national conditions, the motivation and process of exploring the transfer of enterprise personnel into secondary vocational schools have important influence and value for the high-skilled talents in secondary vocational schools in China to establish high-quality teachers, and also for the research and development of other countries. Has a certain reference.

\section{Methods}

The study regards the transformation of individuals from business positions to secondary vocational school positions as a transfer event, and the cause and effect of the individual's idea of transferring jobs is the focus of research. Through the qualitative research, this paper intends to describe and analyze the transfer experience of nine secondary vocational teachers, so as to investigate the mechanism of the transfer incident and classify the image of the transferred teachers.

\section{Objects}

Teacher development is deeply influenced by the environment and the situation, and it has a clear brand of the times. At the same time, the development characteristics of 


\section{Table 1. Transferred Teacher Classification.}

\begin{tabular}{|c|c|c|}
\hline Researcher & Classification & Remarks \\
\hline $\begin{array}{l}\text { Crow, Levine, } \\
\text { Nager (1990) }\end{array}$ & $\begin{array}{l}\text { Returner } \\
\text { (Homecomer) } \\
\text { Changed (Convert- } \\
\text { ed) } \\
\text { Restored (Uncon- } \\
\text { verted) }\end{array}$ & $\begin{array}{l}\text { - "Returnees": Treating teachers as a profession } \\
\text { they have always wanted to return to. } \\
\text { "Changed": Beginning of a career as a career } \\
\text { development plan for an important event or } \\
\text { cause. } \\
\text { - "Restored": Originally chose another profession } \\
\text { because of an important event or reason without } \\
\text { choosing a teacher profession, and achieved a } \\
\text { higher status in the profession, and now re- } \\
\text { selects the teacher profession. }\end{array}$ \\
\hline Ray (1996) & $\begin{array}{l}\text { Modern (Moderns) } \\
\text { Traditional (Tradi- } \\
\text { tionalists) } \\
\text { Achievement } \\
\text { (Achievers) }\end{array}$ & $\begin{array}{l}\text { - "Modern": Personal success is a key factor in } \\
\text { the profession of teachers, because they are } \\
\text { very dissatisfied with their previous life, especial- } \\
\text { ly their career, so they hope to succeed in the } \\
\text { profession of teachers. } \\
\text { - "Traditional": Emphasizes the value of family, } \\
\text { community and work and the profession of } \\
\text { teachers can contribute to the family, community } \\
\text { and society. } \\
\text { "Achievement": I hope to transfer the successful } \\
\text { experience of my previous career to a new ca- } \\
\text { reer (teacher). }\end{array}$ \\
\hline $\begin{array}{l}\text { Anthony, Ord } \\
\text { (2008) }\end{array}$ & $\begin{array}{l}\text { Teachers Do } \\
\text { Good (Look Good) } \\
\text { Type } \\
\text { Suitable Time (Time } \\
\text { Is Right) Type } \\
\text { I Was Fit For Teach- } \\
\text { ing (Teaching Is Me) } \\
\text { Type }\end{array}$ & $\begin{array}{l}\text { - "Being a teacher is not bad": personal pragma- } \\
\text { tism has been frustrated and has no other } \\
\text { choice in the former job. } \\
\text { - "Time is right": The idea of being a teacher for a } \\
\text { long time coincides with the opportunity. } \\
\text { - "I am a teacher": I was attracted to be a teacher } \\
\text { and enjoyed teaching by my positive educational } \\
\text { experience. }\end{array}$ \\
\hline
\end{tabular}

young teachers are most prominent in the first five years or so, and are usually regarded as an important period of development (Zhe, 2000), so the Mesozoic teachers in the process of growth are the focus of research; and they correspond to the 20 jobs. Therefore, it is more practical to select the enterprise experience for more than three years and the teaching age is no more than 10 years. At the same time, the highest purpose of research is to develop high-quality "double-skilled" middle-level teachers, and teachers with enterprise experience can give the greatest advantage in professional teachers' positions. Therefore, the limited research subjects are professional middle-level teachers, and are not involved in ordinary Cultural class teachers, school administrators, etc. Based on this, the image of the research object is determined as: a vocational professional teacher with a background of 5 years or more and a professional background of more than 3 years. The study follows the principle of "sampling of purpose" and "convenient sampling". After finding a qualified transfer teacher in the Shanghai New Teacher Training Class in China, he introduces other transfer teachers through snowball 
sampling. To gradually expand the sample, in-depth study of the group, and finally find the following nine vocational professional teachers who are willing to be interviewed by the enterprise, as the main source of information for this study, the sample basic information is shown in Table 2.

\section{Data Collection}

The study used semi-structured interviews to understand the motives and processes of transfer of secondary vocational teachers. In the early stage, 90-120 minutes of formal interviews were conducted with each teacher. In the course of the interview, teachers were invited to "donely" to talk about the occurrence before and after the transfer. The events, people, feelings, and the thoughts behind the actions of the respondents show the whole process of completing the transfer decision, and the interviewees can no longer think about the ideas and experiences of "transfer". In the later period, the new problems arising from the interview materials were continuously returned through WeChat. All interviews were recorded after notification and consent of the interviewee. At the same time, the video lessons and open classes of the interviewed teachers are used as auxiliary materials for cross-validation at multiple angles.

\section{Date Analysis}

After the interview, the recording will be transcribed with more than 150,000 words and a memo. The original data is subjected to open coding, axial coding, and selective coding in accordance with the Grounded Theory principle. The purpose is to establish a theory based on empirical materials. Firstly, through the repeated reading of the verbatim manuscripts and memos, the nine original materials were logged in openly, and the local concepts in the language of the nine transferred teachers were searched; then, based on this, the formed concept genus was further analyzed and merged. Develop the category and establish the relationship between concepts and generics (Corbin \& Strauss, 1990). Table 3 shows the coding results in part. At the same time, in order to ensure the reliability and reliability of the coding, it is repeatedly discussed in the coding process, and the coding results are reviewed many times and expert opinions are obtained through the Delphi method to improve the accuracy of the coding and the objectivity of the research results.

In the first- and second-level coding results, the core category is selected, and through the verification of the relationship between the core category and other categories in the text data, and the further complement of the incomplete category, the integration is a complete analysis pattern, in which the core The category can be born not only from the existing category, but also from the research needs (Corbin, Strauss, 1990). By combining the first and second level coding results and revisiting the story line, the researchers chose "transfer motivation" as the core category, which is the cause of all stories and the main line of research, including "reasons of separation" and "personal needs". The "reason of separation" describes the dissatisfaction with the former occupation. The sub-categories of the subordinates are: 1 "occupational disorder", which con- 
Table 2. Sample Basic Information.

\begin{tabular}{|c|c|c|c|c|c|c|c|c|}
\hline \multirow[b]{2}{*}{ \# } & \multirow[b]{2}{*}{ Age } & \multirow[b]{2}{*}{$\mathbf{G}$} & \multirow[b]{2}{*}{ Edu } & \multirow[b]{2}{*}{$\begin{array}{l}\text { Learned } \\
\text { Professional }\end{array}$} & \multicolumn{2}{|c|}{ Business Experience } & \multicolumn{2}{|c|}{ Schoolwork } \\
\hline & & & & & Position & $\begin{array}{l}\text { Work } \\
\text { yr }\end{array}$ & $\begin{array}{l}\text { Teaching } \\
\text { Profession }\end{array}$ & $\begin{array}{l}\text { Teach } \\
\text { yr }\end{array}$ \\
\hline $\begin{array}{l}\text { Z- } \\
\text { W0313 }\end{array}$ & 35 & $\mathrm{~F}$ & M's & Garden Design & $\begin{array}{l}\text { Project Man- } \\
\text { ager }\end{array}$ & 8 & Garden Design & 1 \\
\hline $\begin{array}{l}\text { Z- } \\
\text { W0325 }\end{array}$ & 36 & $\mathrm{~F}$ & M's & $\begin{array}{l}\text { Food Science } \\
\text { And Engineer- } \\
\text { ing }\end{array}$ & $\begin{array}{l}\text { Technical } \\
\text { Specialist }\end{array}$ & 9 & $\begin{array}{l}\text { Food Microbio- } \\
\text { logical Testing }\end{array}$ & 1 \\
\hline $\begin{array}{l}\text { M- } \\
\text { W0402 }\end{array}$ & 39 & $\mathrm{~F}$ & M's & $\begin{array}{l}\text { Business Man- } \\
\text { agement }\end{array}$ & $\begin{array}{l}\text { General Man- } \\
\text { ager Secretary }\end{array}$ & 10 & Financial & 1 \\
\hline $\begin{array}{l}\mathrm{L}- \\
\text { W0414 }\end{array}$ & 38 & $\mathrm{~F}$ & $\mathrm{~B}$ & $\begin{array}{l}\text { Software Pro- } \\
\text { gramming }\end{array}$ & $\begin{array}{l}\text { Project Man- } \\
\text { ager }\end{array}$ & 14 & Computer & 1 \\
\hline $\begin{array}{l}\text { X- } \\
\text { W0418 }\end{array}$ & 37 & $\mathrm{~F}$ & M's & Garden Design & $\begin{array}{l}\text { Project Man- } \\
\text { ager }\end{array}$ & 9 & Garden Design & 2 \\
\hline $\begin{array}{l}\text { W- } \\
\text { W0419 }\end{array}$ & 40 & $\mathrm{~F}$ & M's & Garden Design & $\begin{array}{l}\text { Project Man- } \\
\text { ager }\end{array}$ & 10 & Garden Design & 5 \\
\hline $\begin{array}{l}\text { Q- } \\
\text { F0424 }\end{array}$ & 37 & $\bar{M}$ & $\mathrm{~B}$ & $\begin{array}{l}\text { Machine Auto- } \\
\text { mation }\end{array}$ & $\begin{array}{l}\text { Self- } \\
\text { Employment }\end{array}$ & 11 & $\begin{array}{l}\text { Machine Auto- } \\
\text { mation }\end{array}$ & 3 \\
\hline $\begin{array}{l}\text { F- } \\
\text { F0428 }\end{array}$ & 36 & $\mathrm{M}$ & $\mathrm{B}$ & Rail & $\begin{array}{l}\text { Project Man- } \\
\text { ager }\end{array}$ & 11 & Rail & 2 \\
\hline $\begin{array}{l}\text { S- } \\
\text { F0511 }\end{array}$ & 40 & $\mathrm{M}$ & M's & $\begin{array}{l}\text { Mechanical } \\
\text { Design }\end{array}$ & $\begin{array}{l}\text { Project Man- } \\
\text { ager }\end{array}$ & 15 & Rail & 2 \\
\hline
\end{tabular}

Note: G: Gender; F: Female; M: Male; Edu: Education level; M's; Master's Degree; B: Bachelor; yr: Year;

sists of the strength of the former occupational work, the ceiling of occupational development and the emotion of "burnout"; 2 "time freedom", Mainly refers to the low degree of freedom of pre-work hours caused by frequent overtime and business trips. Meanwhile, "time freedom" also appears in "individual needs", which refers to the work that the transferee prefers to have a high degree of freedom in time.

In addition to "time freedom", "personal needs" also includes: (i) "personality traits" mainly describes a series of introspections of the transferee's personality characteristics and ability, in order to find a suitable occupation; (ii) "personal interests" mainly Including: love the profession, love to get along with young people, like simple interpersonal relationship; (iii) "personal ideal" refers to teachers as their own ideals, dreams; (iv) "professional meaning" represents the transfer of education to teachers, teacher value and The recognition of importance. "Transfer motivation" is "matching" behavior with "teacher professional advantage" under the premise of "acquiring recruitment information". "matching" process will be affected by "catalytic factors", such as family support, contact teachers, teaching The approach can greatly improve the possibility of matching success; at the same time, the "obstruction factor" will have a negative effect, such as the risk of lowering the salary, losing the cost of the existing business, and misunderstanding caused by the lack of information. If the match is successful, the concept of "deciding to become a secondary vocational school teacher" is generated. The next step is for the transferee to take action, such as posting resumes and actively interviewing. According to the results of selective coding analysis, the transfer motiva- 
Figure 1. Matching Motivation Model for Transfer of Secondary Vocational Teachers.

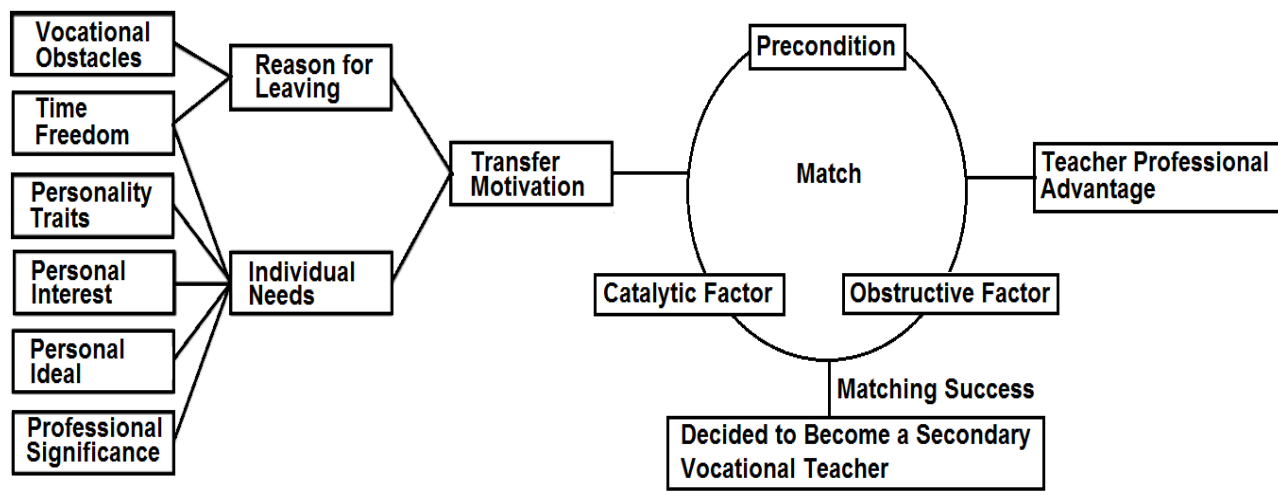

tion matching model of the transfer-oriented vocational teachers is established (see Figure 1).

\section{Cross-Case Study Analysis}

After the third-level coding, the composition factors and matching patterns of the motivation for transfer have emerged from the scattered information, but due to the different life experiences and opportunities of the case, the six sub-categories behind the motivation for transfer (personal interest, time freedom) Degree, professional significance, personal ideals, personality traits, occupational barriers) have different manifestations and focuses on each transfer teacher. In order to deepen the understanding and interpretation of the transfer problem, and to improve the degree of generalization, the study through the continuous comparison of the transfer process of the nine research subjects, find out the similarities and differences of the motivation of transfer, according to the different focus of the transfer motivation The teacher classifies and outlines the "family fulfillment" type, which is driven by "free time", the "starting stove", which is driven by "burnout", and the "long-planned" type, which is driven by "personal ideals". The outline of the transfer teacher; the "individual demand" latitude is the horizontal axis (horizontal degrees of freedom, personality traits, personal interests, personal ideals, professional meanings are arranged from left to right), and the reason for leaving is the vertical axis (from bottom to top) Time freedom, work intensity, career development ceiling, burnout), the intersection of the horizontal and vertical axes is the degree of freedom of time, the distribution of the three types of teachers is shown in Figure 2. At the same time, the common problems in the process of transfer are discussed. The basic 
Figure 2. The Type of Secondary Vocational Teachers Transferred to Enterprises.

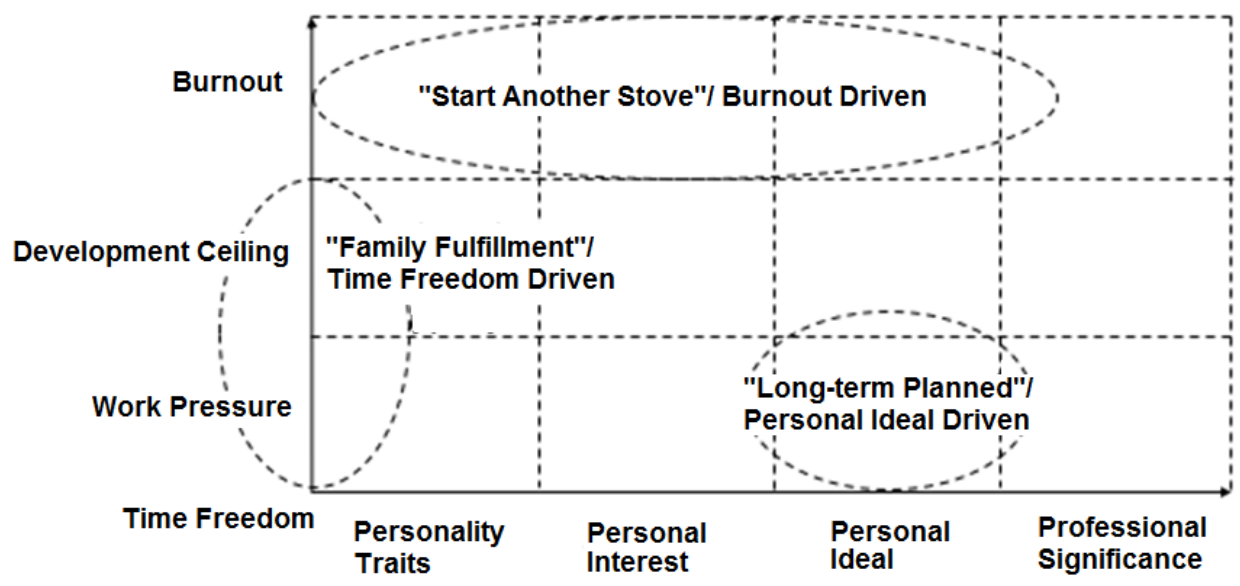

orientation of the analysis process is to preserve the particularity of the case and compare it across cases.

\section{Family and Career Complement Each Other: "Family Fulfillment"}

"At that time, I was basically a project manager in the company. I might say that I have to travel a business all the time. I have to do the project all the time, so the part that takes care of the family is very small, but my child is still very small. But it is really difficult to give up 13 years of work and career, and it is really difficult to start from scratch. At the beginning, I felt that for the children to go out, he had to go to kindergarten. I have to have a lot of energy to accompany him."

"It's because of the children at home, because I used to travel a lot when I was designing, and then the children at home were a little bit at the age of reading, in order to have more, more fixed time to accompany him to study."

"One thing that deeply touched me was that the last time my father was sick, I went back to see him, but because of my work, I could only have one day of vacation. When I left, my father held my hand, although he said nothing. But that look is very disappointing to me. I hope that I can spend more time with my family to spend more time with my family, including my children at home."

"Our industry is a bit of a youthful meal", "It's hard to get a night shift after a certain age", "Power is not enough", "Physical strength can't keep up" and other concepts often appear in the interview materials of female transfer teachers. The ceiling has become a major part of their "occupational barriers". However, at the same time, 


\section{Table 3. Association Code.}

\begin{tabular}{|c|c|c|c|}
\hline \multirow[t]{2}{*}{ Open Coding Extraction Category } & \multicolumn{3}{|c|}{ Relevance Coding Extraction Category } \\
\hline & Subcategory & & Main Category \\
\hline Like what you have learned & \multirow[t]{3}{*}{ Personal interest } & \multirow{8}{*}{$\begin{array}{l}\text { Individual } \\
\text { needs }\end{array}$} & \multirow[t]{12}{*}{ Transfer motivation } \\
\hline Like to get along with young people & & & \\
\hline Don't like complicated relationships & & & \\
\hline The focus of life shifts to the family & \multirow[t]{2}{*}{ Time freedom } & & \\
\hline School is close to home & & & \\
\hline Think that education is important & $\begin{array}{l}\text { Professional } \\
\text { significance }\end{array}$ & & \\
\hline $\begin{array}{l}\text { Being a teacher is my dream from a small } \\
\text { age. }\end{array}$ & Personal ideal & & \\
\hline Personality traits for teachers & Personality Traits & & \\
\hline Pre-vocational time is not free & Time freedom & \multirow{4}{*}{$\begin{array}{l}\text { Reason for } \\
\text { leaving }\end{array}$} & \\
\hline Pre-employment work intensity & \multirow{3}{*}{$\begin{array}{l}\text { Vocational disor- } \\
\text { der }\end{array}$} & & \\
\hline Career development ceiling & & & \\
\hline Burnout & & & \\
\hline Teacher work is guaranteed & \multirow{2}{*}{\multicolumn{2}{|c|}{ Teacher job security }} & \multirow{4}{*}{$\begin{array}{l}\text { Teacher's profes- } \\
\text { sional advantage }\end{array}$} \\
\hline Teachers have winter vacations & & & \\
\hline Good working environment for teachers & \multirow{2}{*}{\multicolumn{2}{|c|}{ Teacher work environment }} & \\
\hline School interpersonal relationship & & & \\
\hline $\begin{array}{l}\text { Occasionally see the recruitment infor- } \\
\text { mation }\end{array}$ & \multirow{2}{*}{\multicolumn{2}{|c|}{ Recruitment information available }} & Precondition \\
\hline Colleague introduction & & & \\
\hline $\begin{array}{l}\text { The school lowered the academic require- } \\
\text { ments }\end{array}$ & \multicolumn{2}{|c|}{ Academic standards } & \\
\hline Get support from family & \multicolumn{2}{|l|}{ Family support } & Catalytic factor \\
\hline Family members in the teacher industry & \multirow{2}{*}{\multicolumn{2}{|c|}{$\begin{array}{l}\text { Have access to teachers and } \\
\text { teaching methods }\end{array}$}} & \\
\hline Friends in the education industry & & & \\
\hline Unwilling to give up his career & \multirow{2}{*}{\multicolumn{2}{|c|}{ Transfer cost }} & Obstructive factor \\
\hline Reduced salary & & & \\
\hline $\begin{array}{l}\text { I didn't know the secondary vocational } \\
\text { school before. }\end{array}$ & \multirow{2}{*}{\multicolumn{2}{|c|}{ Information is not smooth }} & \\
\hline $\begin{array}{l}\text { I don't know if you have a business experi- } \\
\text { ence, you can lower your academic qualifi- } \\
\text { cations. }\end{array}$ & & & \\
\hline
\end{tabular}

the female transferee "has time to look after the family" and "accompanying the child" in the process of leaving the job and choosing a new career is a more important reason than the "occupational disorder". The high requirement for "time freedom" is leading motivation. Therefore, in the process of matching the "transfer motivation" with the "professional advantage of teachers", "there are many teachers and holidays, and there are winter and summer vacations", etc., satisfy the demand of the dominant motive of "time freedom" and "for the sake of children". The belief also defeats the obstacles of "I don't want to give up my career", which greatly increases the possibility of "matching success". 
One interviewee described her and her colleagues as follows: "So I feel that it is not easy to give up the salary of the company because they have sacrificed their own (career) and completed a family wish." The type of transfer teacher is named "family fulfillment" type. Although the "family fulfillment" type of transfer teachers seem to have a more pragmatic motivation to change jobs, this does not mean that they are negative in teaching. In the follow-up study, "family fulfillment" teachers will love and enrich the profession. The experience has poured into the classroom, sparking new passions, injecting new vitality into the classroom, and fulfilling the mutual accomplishment of family and career. One interviewee described this change as a secondary vocational teacher:

"I am very happy to teach, even if they (students) are not able to learn their expectations, but they can find that they (students) are actually working hard, they have fun in the process of learning, satisfaction it will be better than my business project, the customer is very satisfied, and the satisfaction is not the same. And now the work makes me more able to stand on the other side to consider the problem, become softer, and more like a woman, it is more like a mother's perspective to consider the problem."

Through timely guidance, the unfulfilled self-fulfilling desires of the "familycomplete" teachers and the unwillingness to abandon the cause are transformed into passion for education and classrooms, stimulating teachers' pursuit of educational ideals, as Manuel (2006) stated. It is a "teaching as a calling". In the face of the "family fulfillment" type of transfer teachers, schools should play an inspiring and guiding role and actively respond to this "call".

\section{Embark On a New Journey in Life: "Start another Stove"}

Although the transferee who chooses to become a "secondary teacher" because of "personality traits" and "personal interests" often mentioned "I feel that my character is still suitable for being a teacher", "I feel that this young person's management and psychological growth compare Interested in "description, but tracking traceability, can find obvious "burnout" marks.

"After the age of 40, you will start thinking about it. What kind of life you want? You have been busy working hard for the first half of your life. You want to settle down now, want to try something else, and want to change your lifestyle. Try it. I actually have a good professional in front of me, and the professional skills are already very high, but I think that's it. It feels like the end."

"I have done the job as a project manager, but I am really unhappy... Then I am getting tired and tired, I don't like the absolute pursuit of interests, and I am this person. It's quite insecure, and I'm a little scared that I fell off one day when I made a mistake."

"I hope to meet new challenges" and the "boring" feelings of the former profession, "mismatch between values and business", "heart tiredness", etc., reflect the emotional exhaustion of the former work and the decline of professional self-efficacy. The performance of burnout, the transferee began to hope to "open up new areas" and 
"change the environment", by reflecting on their own "personality traits (the characteristics of being a teacher, suitable for teachers, etc.)" and thinking about "personal interests" (like to get along with young people, do not like complex interpersonal relationships, etc.) to find the next occupation, while weighing the "time freedom", "personal ideals" and "professional significance" and other factors. The study classified the transferees who entered the middle-level teachers' team under the leadership of "burnout" as "a new stove" type. Such transfer teachers came to the education field with new ambitions, and at the same time, they were worried about strange fields, an interview. The person smiled and asked: "35 years old, starting from scratch as a secondary vocational teacher, is it quite ridiculous?" To solve this ambition and ambition, secondary vocational schools should help "start another stove" through a series of teacher training. Vocational teachers quickly adapt to the teaching work of teachers, and provide more opportunities to participate in teaching, competition opportunities, etc. to help them "show ambitions" and quickly grow into excellent secondary vocational teachers.

\section{Precautionary Dream Journey: “Long-Planned” Type}

The general conclusion of extensive research abroad over the past decade or so suggests that the choice of teaching is based on internal and altruistic motives, not from external rewards. The biggest motivation is defined as "working with children" "supporting the growth and development of students" and "the desire to contribute to society" (Serow, 1994; Goh, 2001; Richardson, 2006). But for a reason, a job seeker who is eager to be a teacher does not have a teacher as the first choice? Teacher W does not belong to one of the three types summarized by Anthony (2008), and her experience has highlighted the characteristics of professional teachers.

At the beginning of the story, W's positive experience of education has contributed to the ideal of being a teacher.

"I always had this idea when I was in elementary school (being a teacher), because when I was in elementary school, I studied very well in the class. Then I worked as a squad leader. The teacher asked me to give the students a batch of assignments. I felt very successful. Feeling, then the students listened to me very much. At that time, I was very fulfilled. When I wanted to be a teacher, I felt that others would listen to me. Then I could teach those children who could not learn well. This is my dream at that time. Later, I went from junior high school to high school. At that time, our teacher asked the classmates to learn better classmates. In the spare time, I would tell the students some math problems in the front desk. After the lecture, many students said that you said I listened very well, so I felt very fulfilled at that time, so I said that this dream has always been in my heart."

Because of the "sense of teaching accomplishment", W has planted the dream of "being a teacher". In the future, he has always maintained the yearning for the "teacher" profession, and even thinks as a "teacher" role in the personal learning process. 
"It was the same feeling when I was in college. At that time, I thought that the teachers said that I remembered these things, but I really don't use them. I want to say that if I want to be a teacher, how can I tell the students?"

What is amazing is that in this process of thinking, the "personal ideals" led the transfer of teachers to realize that only the textbook theory has no practical experience is "ungrounded", there is no way to teach students well. Therefore, in order to become a good teacher, W began his new learning journey for "accumulating practical experience" after graduation - to enter the enterprise.

"Because when I graduated, my idea was to be a teacher, but I didn't go directly to be a teacher, because I know that as a student, if I go directly to be a teacher, I feel that there is no practical experience. I know that after graduation, I will not do anything, nothing. I may have a sense of proportion to what scales feel, but I can only theoretically, but I really don't have the sense of space. This kind of engineering thing still has to go to you personally, you will really understand it, you can do it well, and you can do it well. For our designers, you have to go to the base, at the base. After a while, you can make a design..."

"I didn't care about salary when I entered the company. I just wanted to learn something, so I could learn something."

After $\mathrm{W}$ realized that his professional knowledge and abilities were gradually completed, his "time" to realize his dreams has matured.

"The most important thing is that I feel that I am almost the same. (Almost meaning?)) It is more mature. In professional, I feel that if I stand on the podium, there is no loss, no deficiency, no one will only follow. The teacher read the theory of textbooks. First, I got a postgraduate degree, and then I learned a lot in the design institute for three years. A project goes down every process, I don't say anything about it, at least I know. In the classroom, if the student asks me something else, I can understand it."

W not only had the dream of "being a teacher", but also wanted to be a "professional teacher", which is mainly influenced by "personal interest (like design)". Entering the enterprise to learn and accumulate experience is to become a person who can become a professional teacher without feeling of false on the podium. In the course of the interview, she joked that this is a "deliberate long-awaited dream", so it will be driven by "personal ideals" and enter the enterprise for the purpose of "doing a better teacher" and in a "just happening" The type of teacher who transferred to work in the time was named "long-planned" type of transfer teacher.

"Remuneration" and "teacher's social status" have proven to be not significant factors influencing job transfer, and career changers usually do not enter the teaching phase for these reasons (Richardson, 2008). However, the gap in "remuneration" will prevent individuals from transferring from enterprises to secondary vocational schools. Therefore, how to cross the gap in pay has become a question worth considering.

"I knew at the beginning that the salary was low, so I was very uncertain before I came."

"The difference in income is very large, one-third to one-half." 
"I (the income is reduced) I must know it in advance, although I don't know how many teachers there are, but definitely lower than in my company."

"My daughter said me, expensive free time."

For the "family fulfillment" type of transfer teachers, it is more important to have time to accompany the family than the high salary, and the accumulation during the work of the company and the income of the other half of the family make them have no worries, which alleviates the gap to some extent. The negative impact brought about by the "other cooker" type of teacher said that "it is definitely not for money to do this." There is no doubt that the negative impact of the salary gap on "long-planned" teachers seems to be less obvious.

"I just want to be a teacher. I want to realize this dream. I actually did it in the design institute for a while. I saw the recruitment information here. When I came over, was it a business unit for our school? Can you come in and prepare? I don't have any questions about salary and treatment. I don't mind this. I just want to be a teacher."

At the same time, corporate transfer teachers can ease the pay gap through a more flexible approach to off-campus part-time work. In addition, interviewees said that although there are many opportunities, they will weigh the choice between school work and family life, and will not be tired of part-time work to make up for the income gap.

"If I want to increase some income, there are actually many opportunities. But if these part-time jobs are done, my income will not be less. But if it takes a lot of time (part time), I think I have chosen (be a teacher), I hope that I will give more time to my family, and I will not do these things."

Off-campus part-time job not only solves the "pay gap", but also helps the transferred teachers to maintain their professional advantages, so that the teaching advantages brought about by the practical experience of the company will not gradually dissipate with the departure of the enterprise, that is, the interviewees I arrived. "I left the company but did not leave the industry." Therefore, "remuneration" has become "a problem not a problem" for the transfer of teachers. Although the "pay gap" constitutes a hindrance factor in the process of transfer, the transfer teacher of the enterprise has found a way to overcome it. However, the lack of management measures for salary incentives in secondary vocational schools, and the fact that teachers' salaries are not proportional to the labor paid, have laid a crisis for the retention of teachers. Since the transferred teachers have rich experience in business practice, they often take more work in their work. For example, "taking a competition" and "taking a scientific research project", etc., are not proportional to the salary compensation, which reduces the teacher's work well-being. In the later stage of teacher development, it causes "painfulness" and may lead to burnout. Over time, a transfer teacher with a corporate background is more likely to change jobs than a teacher as first job. This means that schools attract talent but cannot retain talent. As an interviewee said: "If a school blindly promotes the teacher to sacrifice, it can only explain that its incompetence in management."

\section{Discussion}


Through the analysis of the motives of the secondary vocational teachers who transferred 9 companies, it was concluded that the transfer was triggered by the "individual demand" and the "reasion of separation". According to the specific analysis of the case, it was found that compared with altruistic and intrinsic motivation, pragmatic consideration More prominent, such as: teachers' summer and winter vacations, teachers' working conditions and security, etc., while altruistic motives such as "contributing to society" and "affecting adolescent growth" occur less frequently, which supports the conclusion of Priyadhazini (2003). However, it does not support the findings that "intrinsic and altruistic motives are significantly better than extrinsic motivation" (Serow, 1994; Goh, 2001; Richardson, 2006), which is inconsistent with foreign mainstream views. In other words, the decisions made by individuals in society are bound to be influenced by the big environment (Philippe Bow, 2010), and people's choice of career will also bear the brand of the times (Lv Jianguo, 2000). In China, the importance of secondary vocational education has not been widely recognized. The social status and recognition of secondary vocational teachers are too low to fully stimulate the entry of altruists.

The birth of the "family fulfillment" type of transfer teacher supports Richardson's (2001) view: "For the benefit of the family and improving the quality of family life is a decisive factor in job change, whether through increased income, better job security and satisfaction feeling, or more suitable working hours to take care of and raise children." However, Richardson did not discuss the gender differences in this motivation, and the obvious gender factor in the "family fulfillment" type of transfer teachers in this study is consistent with the current situation of Chinese women's social division of labor, that is, compared with men, "family" becomes Women's important factors in the career planning process (Liu, 2000), women are more likely to be hindered by professional development and choices by non-market factors (such as caring for the family and doing housework), and have to fall into the dilemma of balancing occupations and families (Fu, 2005). This is also in line with the imbalance between the male and female teachers in China's secondary vocational schools and the lack of attractiveness of teachers' occupations to men (Zhou, 2007), but it does not mean that there will be no "family fulfillment" in male transfer teachers.

The "starts another stove" type is obviously different from the "look good" type of Anthony (2008). "look good" emphasizes the unsuccessful pre-job and has no choice, and the "starts another stove" type teacher brings new The ambition came to the field of vocational education, full of expectations for the challenge, eager to find new self-worth in the teacher's position, and not helpless.

The "long-planned" type is not the same as the "returnee" of Crow (1990). From the action track, both of them regard the teacher as their own career and enter the teaching at an appropriate time. However, the "deliberately long-term" type of transfer teachers are more motivated and vocational education features: individual business work experience is a kind of learning and preparation for becoming a professional teacher. The failure to use the teacher as the first occupation is an individual's positive self-selection, and it is not helpless to "missing the shoulders". 
The study depicts three types of transfer teachers based on the similarities and differences of the motivations of the nine subjects, but the purpose of the study is not to exhaust all types and classifications as a goal, but to profoundly depict and explain At this stage, we strived to contribute to the recruitment of transferred teachers and to pave the way for continuous research.

\section{Conclusions}

The study finds that "reasons of separation" and "individual needs" are the two main categories that constitute "transfer motivation"; "transfer motivation" under the influence of "preconditions", "catalytic factors" and "obstructive factors" and "The teacher's professional advantage is matched, and if the match is successful, the idea of "deciding to become a secondary vocational teacher" is generated and put into action.

According to the different motivations of transfer, they are divided into "familycomplete" type with "free time" as the main motive, "other-starting" type with "job burnout" as the motive, and "personal ideal" as the dominant motive - a long-deployed type of transfer teacher.

The problem of "income gap" caused by the transfer of jobs does not prevent individuals from transferring from enterprises to secondary vocational schools, but the low salary of teachers will affect teachers' happiness.

\section{Suggestion}

The establishment and development of a "double-type" teacher team that "gets into the classroom and has a good teaching in the factory" requires the joint efforts of the state and society. Continuously give vocational education development support, improve the quality and quantity of secondary vocational teachers; high-skilled personnel with enterprise experience and industry background should be classified as the key attraction. Introduce them to the ranks of secondary vocational teachers and evoke new vitality.

\section{School-Enterprise Cooperation Goes Deep into the Talent Flow Level}

School-enterprise cooperation can not only create opportunities for students to practice learning, but also be a viable channel for introducing enterprise technical talents. The school-enterprise cooperation channel is used as a means of publicizing and recruiting teachers, increasing the opportunities for enterprise technical talents to contact education, and helping to catalyze the transfer of technical personnel into the teaching staff. Encourage enterprise technicians to enter the school to experience teaching, feel the "education call", and strive for the transition from full-time teachers to full-time teachers. At the same time, it provides the transition period of the teacher's role and the observation period of the school's teacher quality, which is conducive to recruiting and retaining high-quality teachers. The state and society should create a good atmosphere of respecting and advocating occupations, increase the propaganda of secondary voca- 
tional education, and constantly improve the social status and professional recognition of secondary vocational teachers to stimulate the participation of altruists. Therefore, the focus of publicity can be on "accommodating young people's growth" and "contributing to society".

\section{Establish and Improve the Incentive Mechanism for Second- ary Vocational Teachers}

In a market economy environment, the most obvious way to attract more outstanding teachers to the position of teachers is to improve the working conditions of teachers (John Rolls, 2009). On the one hand, it is to establish sound and reasonable material rewards, and to give reasonable material rewards to teachers who have undertaken more scientific research tasks, competition projects, and outstanding teaching results to encourage teachers to tap their potentials to develop their strengths. At the same time, it gives reasonable rewards to teachers' efforts, improves work well-being and prevents burnout. At the same time of material incentives, each teacher should take care of each other's own development needs, different subjective perceptions, and different objective environments, so as to deeply understand the development needs of secondary vocational teachers, adopt a flexible reward system, and mobilize the enthusiasm of teachers through differential incentives. On the other hand, teachers who are transferred to the school are encouraged to participate in the construction of schools and majors, improve the voice and participation of teachers who are transferred, and encourage teachers to deepen their sense of identity with schools and positions.

\section{Building a Diverse Support Policy for Teacher Development}

Actively establish support policies for the development of transfer teachers, and open a diversified teacher development path. For those who have medium and high-level technical titles and are willing to teach at the vocational school, they should provide support and help for the conversion of titles after the passing of the examination, and open up the channel for conversion between "double titles". Establish a new teacher training system for transfer teachers, make up for the shortcomings of transfer teachers in teaching, and give full play to the long-term professional skills of transferred teachers. At the same time, the "Moral Education Teacher's Morality" is the focus of the induction training for transfer teachers, and the teacher's normality of the transferred teachers should be improved. There is a focus on school assignments and job placement. For example, "starts another stove" teachers who have professional skills and business experience and are eager to show their ambitions can play a greater role in competitions, training programs and professional construction. 


\section{References}

Anthony, G., \& Ord, K. (2008) Change-ofcareer secondary teachers: motivations, expectations and intentions. A P J Teach Edu, 36(4): 359-376.

Chen, X.M. (1999) Thoughts and methods of grounded theory. Edu Res Exp, (4): 58-63.

Corbin, J., \& Strauss, A. (1990) Grounded theory research: procedures, canons, and evaluative criteria. Qual Sociol, 19(6): 418-427.

Crow, G.M., Levine, L., \& Nager, N. (1990) No more business as usual: career changers who become teachers. Am J Edu, 98(3):197-223.

DEST [Department of Education, Science and Training]. (2003) Australia's teachers: Australia's future - Advancing innovation, science, technology and mathematics. Canberra: Commonwealth Department of Education, Science and Training

Fu, X. (2005) Introduction to Gender Research . Peking University Press, 92-98.

Goh, K.C., \& Atputhasamy, L. (2001) Teacher education in Singapore: what motivates students to choose teaching as a career? Paper presented at the Australian Association for Research in Education Annual Conference, Fremantle, Western Australia.

John, R. (2009) Theoray of Justice . He, H.H., et al. Beijing: China Social Sciences Press, 321-328,413,418,452,336-337.

Lerner, P.K., \& Zittleman, K. (2002) Career changers: women (and men) who switch to teaching. Paper presented at the American Educational Research Association Annual Conference, New Orleans.

Liu, D.Z., \& Niu, Z.X. (2000) Professional gender segregation and female employment in China. Women Stud, (4):18-20.

Long, C.H., \& Peng, Y.X. (2009) On the professional background of teachers and the cultivation of students' professional culture. Chin Electr Power Edu, (8): 15-16.
Lu, J.G. (2000) Vocational Psychology. Dongbei University of Finance and Economics Press, 194-232.

Manuel, J., \& Hughes, J. (2006) 'It has always been my dream': exploring preservice teachers' motivations for choosing to teach. Teach Dev, 10(1):5-24.

Philip, B. (2010) Predicting society: the inner law of group behavior: how one thing leads to another. 2nd Ed. Contemporary China Press, 236-245.

Priyadharshini, E., \& Robinsonpant, A. (2003) The attractions of teaching: An investigation into why people change careers to teach. J Edu Teach, 29(2):95-112.

Richardson, P., \& Watt, H. (2006) Who chooses teaching and why? Profiling characteristics and motivations across three Australian universities. A P J Teach Edu, 34(1):27-56.

Richardson, P., Gough, J., \& Vitlin, M. (2001) Becoming a mature-aged teacher: career change into teaching. Paper presented at the Australian Association for Research in Education Annual Conference, Fremantle, Western Australia.

Salyer, B. (2003) Alternative and traditionally certified teachers: the same but different. NASSP Bull, 87(636), 16-27.

Serow, R., \& Forrest, K. (1994) Motives and circumstances: occupational-change experience of prospective late-entry teachers. Teach Teach Edu, 10(5):555-563.

Yu, J.Y., \& Li, Q.Z. (2007) Verification of marketing hypothesis by applying grounded theory. Finan Trad Econ, (11):65-70.

Zhang, S.Y. (2013) A summary of studies on foreign transfer teachers since the 1990s. Foreign Edu Res, (5): 95-102.

Zhong, K.D., \& Zhang, Y. (2000) Research on the development law and influencing factors of teachers' strategic knowledge. Psychol Sci, 23(4):488-490. 
Xu \& Zhang. Transferring Motivation from Enterprises to Vocational School Teachers.

Zhou, J.W. (2007) The causes of the unbalanced gender structure of primary and secondary school teachers and its coun-

termeasures. Teach Manag, (18):28-29.

Received: 23 August 2019

Revised: 04 September 2019

Accepted: 12 October 2019 